\title{
Analisis Pelanggaran Prinsip Kesantunan pada Naskah Drama Tik Karya Budi Yasin Misbach dalam Antologi Bengkel Penulisan Naskah Drama Dewan Kesenian Jakarta (Tinjauan Pragmatik)
}

\author{
Abdul Malik $^{1}$, Winda Dwi Hudhana ${ }^{2}$ \\ Universitas Muhammadiyah Tangerang \\ Windhana89@gmail.com
}

\begin{abstract}
Abstrak
Tujuan penelitian ini adalah menganalisis dan mendeskripsikan pelanggaran prinsip kesantunan yang terdapat di dalam dialog naskah drama Tik karya Budi Yasin Misbach, dalam Antologi Bengkel Penulisan Naskah Drama Dewan Kesenian Jakarta. Metodologi pada penelitian ini yaitu metode analisis isi. Pelanggaran yang terdapat pada analisis pelanggaran prinsip kesantunan pada naskah drama Tik karya Budi Yasin Misbach, dalam Antologi Bengkel Penulisan Naskah Drama Dewan Kesenian Jakarta. Naskah yaitu 1) pelanggaran maksim penghargaan; 2) pelanggaran maksim kerendahan hati; 3) pelanggaran maksim mufakat; dan 4) pelanggaran maksim simpatisan.
\end{abstract}

Kata Kunci: pelanggaran prinsip kesantunan, drama

\section{A. Pendahuluan}

Pemakaian bahasa bukan hanya sarana untuk berkomunikasi, tetapi juga pemakaian bahasa dalam sastra karena bahasa merupakan media utama dalam sastra. Hal ini tentu sangat berbeda antara bahasa sebagai media sastra dengan sastra sebagai media komunikasi agar dapat membedakan bahasa sebagai media komunikasi dan bahasa sebagai media sastra. Bahasa sastra memang berbeda dan mempunyai ciri tersendiri yang khas, justru dari kekhasan tersebut merupakan kekuatan karya sastra yang diciptakan oleh pengarang. Hal inilah yang menyebabkan pengarang selalu berusaha untuk membuat gaya bahasa yang menjadi ciri khas dirinya, baik yang berkaitan dalam unsur bahasa maupun bentuk perasaan yang di ungkapkan dalam sastra.

Pada sebuah drama dialog merupakan situasi bahasa yang utama. Dialog yang berada di dalam naskah drama merupakan hal terpenting dalam naskah drama. Bahasa dalam naskah drama sangatlah berbeda dengan karya sastra lain, seperti puisi dan novel. Drama biasanya dititik 
beratkan pada tiga aspek utama yaitu naskah atau dialog, alur cerita dan tata panggung. Situasi bahasa dialog silih berganti, para pelaku dialog berbicara, di dalam drama tradisional di katakan "ideal" para pemain bergantian dan tidak saling potong, atau tidak menyimpang dari bahan pembicaraan. Biasanya lawan bicara berada dalam ruang yang sama pada waktu yang sama yang dinamakan "latar" dalam sebuah dialog, dalam pementasan drama teks merupakan hal yang terpenting. Drama merupakan bentuk sastra yang menggambarkan kehidupan dalam bentuk teks atau naskah. Seperti bentuk-bentuk sastra lainnya, sebuah cerita drama pun harus bergerak dari suatu permulaan, melalui suatu bagian tengah, menuju suatu akhir, yang biasa di sebut alur. Yang membedakan bentuk sastra drama dengan bentuk sastra yang lainnya yaitu pemain, ritme dan tata panggung.

Keberhasilan suatu karya sastra diukur dari pembacanya. Karya sastra yang berhasil yaitu karya sastra yang dianggap mampu memberikan kesenangan dan nilai. Walaupun dimensi pragmatik melingkupi pengarang dan pembaca, pembacalah yang dominan. oleh karena pembaca menjadi penentu pemahaman karya sastra, kemampuan kebahasaan pembaca sangat menentukan. Dalam pragmatik ada dua hal penting yang perlu dicermati yakni penggunaan bahasa dan konteks, jadi penggunaan bahasa ini menyagkut fungsi bahasa, yaitu fungsi untuk menyampaikan, pengungkapan sikap dan prilaku penutur, dan sebagai menyusun kalimat lisan maupun tulisan. Sedangkan konteks terkit dengan hal yang harus diperhatikan dalam penggunaan bahasa khususnya dalam masyarakat, harus memperhatikan prinsip kesantunan yang berlaku di lingkunan masyarakat yang berbeda-beda, dikarnakan perbeda ini disebabkan adanya perbedaan kebudayaan, adatistiadat dan agama disetiap daerah. Maksim juga disebut sebagai bentuk pragmatik berdasarkan prinsip kerja sama dan prinsip kesantunan. Maksim-maksim tersebut menganjurkan agar kita mengungkapkan keyakinan-keyakinan dengan sopan dan menghindari ujaran yang tidak santun. Maksim-maksim ini dimasukkan ke dalam kategori prinsip kesantunan. Dari prinsip-pinsip tersebut, terdapat empat maksim yang melibatkan skala-skala berkutub dua, yakni skala untung-rugi dan skala puji-kecaman. Keempat maksim tersebut adalah maksim kebijaksanaan, maksim kedermawanan, maksim penghargaan, dan maksim kesederhanaan. Sedangkan dua maksim lainya maksim mufakat dan maksim simpatisan melibatkan skala-skala yang hanya satu kutubnya, yaitu skala kesepakatan dan skala simpati. Walaupun antara skala yang satu dengan yang lain ada kaitannya, setiap maksim berbeda dengan jelas, karena setiap 
maksim mengacu pada sebuah skala penilaian yang berbeda dengan skala penilaian maksimmaksim lainnya.

Peneliti tertarik untuk menganalisis naskah drama sebagai objek penelitian dari segi pelanggaran prinsip kesantunan, dikarnakan pengarang naskah drama seringkali tidak memperhatikan kaidah-kaidah dari segi kesopanan, dikarnakan drama merupakan gambaran hidup manusia yang di tampilkan dalam gerak. Pengarang seringkali menggunakan bahasa keseharian yang terdapat di suatu lingkungan yang akan di jadikan acuan dalam naskah, karena naskah drama yang berjudul Tik karya Budi Yasin Misbach ini terinspirasi dari sekelompok masyarakat yang tinggal di tempat pembuangan sampah, tetapi pengetahuan mereka luas karena setiap hari mereka membaca koran bekas yang berada di sekitar mereka. Tujuan penelitian ini adalah menganalisis dan mendeskripsikan pelanggaran prinsip kesantunan yang terdapat di dalam dialog naskah drama Tik karya Budi Yasin Misbach, dalam Antologi Bengkel Penulisan Naskah Drama Dewan Kesenian Jakarta.

\section{B. Kajian Teori}

Drama berasal dari bahasa Yunani yaitu draomai atau dran, artinya bertindak, berlaku, berbuat, beraksi. Drama merupakan kualitas komunikasi, situasi, action (segala yang terlihat di pentas) yang menimbulkan perhatian, kehebatan (axciting), dan ketegangan pada para pendengar. Kosasih (2008) drama adalah bentuk karya sastra yang bertujuan menggambarkan kehidupan dengan menyampaikan pertikaian dan emosi melalui lakuan dan dialog (h.81). Selain itu, menurut Rendra (2013) drama atau sandiwara adalah seni yang mengungkapkan pikiran atau perasaan orang dengan mempergunakan laku jasmani dan ucapan kata-kata (h.84). sejalan dengan hal tersebut menurut Rahardi (2009) pragmatik adalah studi bahasa yang mendasarkan pijakan analisisnya pada identitas konteks. Adapun konteks yang dimaksud adalah segala latar belakang pengetahuan yang dimiliki bersama oleh penutur dan mitra tutur dan yang menyertai dan mewadahi pertuturan tertentu (h.22).

Leech (2015) pragmatik adalah studi tentang makna dalam hubungannya dengan situasisituasi ujar (speech situation) (h.8). Jadi pragmatik merupakan kajian kebahasaan yang membahas makna tetapi bukan hanya sekedar makna dalam konteks kebahasaan seperti halnya kajian linguistik pada umumnya tetapi pragmatik membahas makna dengan situasi yang terjadi 
Lingua Rima: Jurnal Pendidikan Program Studi Bahasa dan Sastra Indonesia

Vol.6 No.2 Juli 2017

pada waktu tertentu. Kajian pragmatik lebih di tekankan kepada kajian antardisiplin antara bahasa dengan konteks (di luar bahasa). Dalam penggunaanya memahami hakikat bahasa harus menyentuh permasalahan di luar bahasa yang lebih luas, termasuk bagaimana bahasa digunakan dalam berkomunikasi. Ada enam maksim menurut Leech (2015) yakni:

1. Maksim Kearifan (tact maxim). Menurut leech (2015) buatlah Kurangi kerugian orang lain sekecil mungkin. Tambahi keuntungan orang lain sebesar mungkin (h.206). Perkataan lain menurut maksim ini, kesantunan dalam bertutur dapat dilakukan apabila maksim kebijaksanaan dilaksanakan dengan baik. Menurut Sulistyo (2013) maksim kearifan, dalam bertutur dianggap baik apabila maksim kearifan dilakukan dengan baik, intinya adalah buatlah kerugian orang lain sekecil mungkin, dan buatlah keuntungan orang lain sebesar mungkin (h.27).

2. Maksim Kedermawanan (generosity maxim). Menurut Leech (2015) maksim kedermawanan ini mengungkapkan buatlah keuntungan diri sendiri sekecil mungkin, buatlah kerugian diri sendiri sebesar mungkin (h.206). Maksim kedermawanan ini, para peserta pertuturan diharapkan dapat menghormati orang lain.

3. Maksim Penghargaan atau Pujian (approbation maxim). Menurut Leech (2015) maksim pujian adalah kecamlah orang lain sedikit mungkin, pujilah orang lain sebanyak mungkin (h.207). Agar setiap penutur sedapat mungkin menghindari mengatakan sesuatu yang tidak mengenakan orang lain, terutama kepada orang yang diajak bicara (lawan tutur).

4. Maksim Kerendahan Hati (modesty maxim). Menurut Leech (2015) menyatakan bahwa maksim kerendahan hati ini pujilah diri sendiri sedikit mungkin, kecamlah diri sendiri sebanyak mungkin (h.207). Bila kemurahan hati berpusat pada orang lain, maksim ini berpusat pada diri sendiri. Maksim ini menuntut setiap peserta pertuturan untuk memaksimalkan ketidak hormatan pada diri sendiri, dan meminimalkan rasa hormat pada diri sendiri.

5. Maksim Mufakat (agreement maxim). Menurut Leech (2015) bahwa maksim mufakat yaitu usahakan agar kesepakatan antar diri dan lain terjadi sedikit mungkin, usahakan agar kesepakatan antar diri dengan lain terjadi sebanyak mungkin (h.207). Jika lawan tutur mendapatkan kesuksesan atau kebahagiaan, penutur wajib memberikan ucapan selamat. Bila lawan tutur mendapatkan kesusahan atau musibah, penutur layak berduka cita, atau mengutarakan ucapan bela sungkawa sebagai tanda kesimpatian, yakni 
memaksimalkan rasa simpati kepada lawan tuturnya yang mendapatkan kebahagiaan dan kedukaan.

6. Maksim Simpatisan (sympathy maxim). Menurut Leech (2015) menuturkan maksim simpati dengan tuturan kurangilah rasa antipati antar diri dengan lain hingga sekecil mungkin, tingkatkan rasa simpati sebanyak-banyaknya antar diri dan yang lain (h.207). Jika lawan tutur mendapatkan kesuksesan atau kebahagiaan, penutur wajib memberikan ucapan selamat. Bila lawan tutur mendapatkan kesusahan atau musibah, penutur layak berduka cita, atau mengutarakan ucapan belasungkawa sebagai tanda kesimpatian, yakni memaksimalkan rasa simpati kepada lawan tuturnya yang mendapatkan kebahagiaan dan kedudukan.

\section{Metodologi Penelitian}

Sesuai dengan penelitian yang dilakukan dalam penelitian ini bertujuan untuk meneliti naskah drama, maka penulis menggunakan metode analisis isi (content analysis). Karena metode analisis isi menurut peneliti cocok dengan judul yang akan diteliti dengan judul penelitian “Analisis Pelanggaran Prinsip Kesantunan Pada Naskah Drama Tik karya Budi Yasin Misbach, dalam Antologi Bengkel Penulisan Naskah Drama Dewan Kesenian Jakarta.

Sumber data yang dijadikan acuan dalam penelitian ini, baik berupa fakta dalam penelitian ini maupun berupa analisis pelanggaran prinsip kesantunan pada naskah drama Tik karya Budi Yasin Misbach, dalam Antologi Bengkel Penulisan Naskah Drama Dewan Kesenian Jakarta. Naskah drama ini di terbitkan oleh penerbit buku Ultimus, pada tahun 2013. Jenis data yang akan dianalisis yaitu berupa kutipan dalam kalimat atau dialog yang di dalamnya terdapat pelanggaran prinsip kesantunan dalam naskah drama Tik karya Budi Yasin Misbach, dalam Antologi Bengkel Penulisan Naskah Drama Dewan Kesenian Jakarta.

Teknik pengumpulan data yang digunakan ketika menganalisis data darata dari sumber data yang menjadi fokus penelitian. Untuk menganalisis data dibutuhkan langkah-langkah yang akan dilakukan yakni : 1) membaca data sumber utama yaitu naskah drama Tik karya Budi Yasin Misbach, dalam Antologi Bengkel Penulisan Naskah Drama Dewan Kesenian Jakarta, secara keseluruhan untuk memahami isi naskah drama secara berulang-ulang; 2) Setelah itu mencari dan menemukan kalimat-kalimat yang menyatakan pelanggaran prinsip kesantunan dalam naskah drama Tik karya Budi Yasin Misbach, dalam Antologi Bengkel Penulisan Naskah Drama Dewan Kesenian Jakarta, 3) Mencatat kalimat yang terdapat dalam naskah drama Tik Karya Budi 
Yasin Misbach, dalam Antologi Bengkel Penulisan Naskah Drama Dewan Kesenian Jakarta, 4) Mengklasifikasikan kalimat yang mengandung pelanggaran prinsip kesantunan dalam naskah drama Tik Karya Budi Yasin Misbach, dalam Antologi Bengkel Penulisan Naskah Drama Dewan Kesenian Jakarta; 5) Melakukan pengecekan kembali secara berulang-ulang untuk mendapatkan data yang sesuai dengan pelanggaran maksim kesopanan.

Tehnik analisa data yang digunakan dalam penelitian ini menggunakn model analisa mengalir, yang meliputi: 1) reduksi data yaitu data-data yang dipilih hanya data yang berkaitan denagn masalah yang akan dianalisis, dalam hal ini tentang pelanggaran prinsip kesantunan yang terdapat dalam naskah drama Tik karya Budi Yasin Misbach, dalam Antologi Bengkel Penulisan Naskah Drama Dewan Kesenian Jakarta. Informasi-informasi yang mengacu pada permasalahan itulah yang menjadi data dalam penelitian ini; 2) penyajian data yaitu data-data yang sudah diperoleh dapat mempermudah pemahaman penelitian dalam menganalisis data kemudian dicari untuk mendapatkan pelanggaran prinsip kesantunan. Data-data tersebut kemudian dianalisis sehingga memperoleh deskripsi tentang pelanggaran maksim kesopanan; 3) menarik simpulan yaitu ada tahap ini dibuat kesimpulan tentang hasil dari data yang diperoleh sejak awal penelitian.Kesimpulan ini masih memerlukan adanya verifikasi (penelitian kembali tentang kebenaran laporan) sehingga hasil yang diperoleh benar-benar valid.

\section{Pembahasan}

Pada temuan analisis pelanggaran prinsip kesantunan pada naskah drama Tik karya Budi Yasin Misbach, dalam Antologi Penulisan Bengkel Penulisan Naskah Drama Dewan Kesenian Jakarta ini banyak terdapat pelanggaran prinsip kesantunan dikarnakan naskah drama ini mempunyai latar belakang pemain yang hidup di tempat pembuangan sampah. Berikut ini bentuk pelanggaran maksim kesopanan:

1. Pelanggaran Maksim Penghargaan

Maksim penghargaan ini diharuskan untuk mengurangi cacian pada orang lain dan menambahkan pujian pada orang lain. Penutur yang selalu mematuhi maksim penghargaan ini akan dianggap sebagai orang yang mengetahui sopan santun. Jika penutur mempunyai kepribadian mematuhi maksim penghargaan ini, maka hubungan penutur dan mitratutur akan terjalin dengan baik. Karena penutur dan mitratutur akan saling menghargai satu sama lain dan akan terjauh dari tuturan yang tidak baik dari lawan tuturnya. 
Lingua Rima: Jurnal Pendidikan Program Studi Bahasa dan Sastra Indonesia

Vol.6 No.2 Juli 2017

Petugas Satu : saudara wardana bin mudakir kenapa anda mencuri televisi?

Wardana : karena saya tidak punya televise

Petugas satu : maksud saya, untuk apa?

Wardana : supaya saya punya, dan bisa nonton bersama istri dan teman-teman saya

Petugas satu : Tapi kan, kamu bisa membelinya!

Wardana : Saya tidak punya uang pak

Petugas satu : Tidak punya uang kok mau punya televisi memanggnya kerjaan kamu $\underline{\text { apa? }}$

Wardana : pemulung.(h.56).

Penutur di atas melanggar prinsip kesantunan dengan maksim penghargaan diutarakan dengan kalimat ekspresif dan asertif. Dengan penggunaan kalimat ekspresif dan asertif ini jelaslah bahwa tidak hanya menyuruh dan menawarkan seseorang harus berlaku sopan, tetapi di dalam mengungkapkan perasaan, dan menyatakan pendapat ia tetap diwajibkan berperilaku demikian. Tindak tutur petugas satu menyatakan tindakan melanggar Prinsip Kesantunan dengan Maksim Penghargaan Petugas satu berpendapat "Tidak punya uang kok mau punya televisi memanggnya kerjaan kamu apa?" padahal wardana menjawab pertanyaan Petugas Satu dengan tuturan baik. Karena tuturan tersebut memaksimalkan cacian pada orang lain dan meminimalkan pujian pada orang lain, tuturan tersebut menyatakan melanggar Prinsip Kesantunan.

Petugas satu : Kamu tahu omongan ekskutif dari mana, sampe bisa nyontek segla. Kan gak punya tivi?

Wardana : Baca Koran, pak! Setiap hari saya rajin membaca, karena setiap hari juga saya selalu mendapat Koran. Meskipun Koran bekas, yang penting masi bisa dibaca!

Petugas satu : Berbahaya! Pasti kamu bukan seperti orang yang kamu jelaskan tadi. Kamu punya maksud tertentu yang belum sempat terungkap di sini.kamu menyelinap ya? (h.56).

Tuturan yang dilakukan oleh Petugas satu tidak enak didengar atau tidak sopan dan melecehkan Wardana karena Wardana pemulung dan tidak punya televisi, seperti pada kalimat “Kamu tahu omongan ekskutif dari mana, sampe bisa nyontek segla. Kan gak punya tivi?”, karena pembicaraan wardana ini menggunakan bahasa yang biasa di gunakan oleh para pejabat sehingga petugas satu merasa curiga terhadap, Wardana kalau wardana ini ada tujuan lain agar bisa masuk kedaerah petugas seperti pada kutipan dialog, "Berbahaya! Pasti kamu bukan seperti orang yang kamu jelaskan tadi. Kamu punya maksud tertentu yang belum sempat terungkap di sini.kamu menyelinap ya?". Tuturan tersebut bahwasannya petugas satu 
Lingua Rima: Jurnal Pendidikan Program Studi Bahasa dan Sastra Indonesia

Vol.6 No.2 Juli 2017

menganggap, Wardana bukan hanya maling televisi tetapi ada untuk menyelinap dan beruk sangka.

$\begin{array}{ll}\text { Petugas satu } & : \text { Kenapa, takut? } \\ \text { Petugas tiga } & \text { : Sedikit! } \\ \text { Petugas dua } & \text { : goblok! } \\ \text { Petugas tiga } & \text { : Gemeteran.... } \\ \text { Petugas dua } & : \text { kebanyakan sih, semalaman tiga orang di genjot! } \\ \text { Petugas tiga } & \text { : Habis semuanya kepengen.(h.70). }\end{array}$

Dalam tuturan para petugas diatas tentunya tidak sopan dikarnakan mengandung ejekan atau cacian contohnya "goblok!" kata goblok merupakan panggilan orang yang memang bodoh, hal ini tentunya dapat menyinggung perasaan lawan tuturyang merasa diriny tidak bodoh. Maka tuturannya di atas masuk dalam tuturan yang melanggar prinsip kesantunan dengan maksim penghargaan, Karena tuturan tersebut memaksimalkan cacian pada orang lain dan meminimalkan pujian pada orang lain, tuturan tersebut menyatakan melanggar prinsip kesantunan.

2. Pelanggaran Maksim Kerendahan Hati

Maksim Kerendahan Hati ini mewajibkan penutur untuk selalu rendah hati dan memaksimalkan cacian pada dirinya sendiri. Penutur yang menaati maksim ini akan dianggap sebagai seorang yang rendah hati dan tidak sombong. Pelanggaran terhadap maksim kerendahan hati secara terus menerus akan membentuk kepribadian yang sombong, bersikap anti sosial, dan bahkan yang terburuk penutur seperti itu akan dijauhi lawan tuturnya, karena bagai manapun komunikasi dengan orang yang selalu melanggar maksim kerendahan hati akan sangat tidak nyaman.

Petugas satu : Sayakan tadi Cuma memperingatkan supaya omongan kamu itu jangan ngawur. Ini kantor petugas keamanan. Jadi kamu jangan seenaknya saja, ngeluarin bacot dan saya yang bertugas disini bertangguang jawab atas segala keamanan yang terjadi di kampung ini mengerti

Wardana $\quad$ : Ngerti pak! (h.57).

Tuturan yang diucapkan oleh, Petugas satu tidak enak didengar karena menyombongkan diri contohnya pada kalimat," Ini kantor petugas keamanan. Jadi kamu jangan seenaknya saja, ngeluarin bacot dan saya yang bertugas disini bertangguang jawab atas segala keamanan yang terjadi di kampung ini mengerti". Petugas satu bermaksud untuk menegaskan kepada wardana agar tidak seenaknya berbica, karena petugas merasa tersinggung dengan jawaban wardana atas introgasinya. Dalam tuturan di atas tentunya melanggar prinsip kesantunan dengan maksim 
kerendahan hati, karena si penutur memaksimalkan pujian pada diri sendiri, dan meminimalkan kecaman pada diri sendiri. tuturan tersebut menyatakan melanggar prinsip kesantunan.
Wardana
: Sekarang Bapak yang sudah mulai bertele-tele. Sebenarnya, saya jadi di tangkap gak sih, Pak?
Petugas satu
Wardana
: ditangkap tapi dengan tuduhan pasal yang berlapis
Petugas satu
: Apa itu, pak? Memangnya selain mencuri saya di tuduh apa lagi?
: terlibat persekongkolan untuk mengacaukan stabilitas keamanan di kota ini. Dan ini sangat berbahaya karena merongrong kewibawaan otoritas di sini (h.60).

Tuturan yang diucapkan oleh, Petugas satu tidak sopan karena menyombongkan diri contohnya pada kalimat,"dan ini sangat berbahaya karena merongrong kewibawaan otoritas di sini”. Petugas satu beranggapan bahwa dirinya telah di permainkan dan diganggu oleh Wardana. Dalam tuturan di atas tentunya melanggar prinsip kesantunan dengan maksim kerendahan hati, karena si penutur memaksimalkan pujian pada diri sendiri, dan meminimalkan kecaman pada diri sendiri. tuturan tersebut menyatakan melanggar prinsip kesantunan.

\section{Pelanggaran Maksim Mufakat}

Maksim mufakat ini diwajibkan untuk meminimalkan ketidak sesuaian antara dirinya dengan yang lain. Penutur yang menaati maksim mufakat ini akan dianggap sebagai seorang yang santun dan selalu memperhatikan apa yang dibicarakan oleh lawan tuturnya. Dalam maksim mufakat ini pelaku pelanggaran terhadap maksim mufakat ini akan dianggap sebagai seorang yang tidak santun dan tidak berwawasan luas. Yang terburuk, lawan tutur akan merasa enggan berkomunikasi dengannya.

Petugas satu : Saya tetap tidak setuju. Tidak mudah menghadirkan beliau ketempat ini. Ini semacam memperlambat proses penahanan kamu.

Seseorang : Loh gimana sih? Menghadirkan korban kok dianggap memperlambat penahanan...? Bukannya malah mempercepat pak?

Petugas satu : Pak Haji Komar orang sibuk, tidak mungkin hari ini diundang, hari ini juga datang. Jadi inilah yang memperlambat.

Seseorang : Kalau begitu kami saja yang mengundang. Bapak-bapak di sini saja, gak usah nyari! Biar kami saja! Ayo, siapa yang mau ikut KEPADA KAWANNYA YANG LAIN.

Seseorang : Saya!

Seseorang : Ok. Mari kita berangkat! MERDEKA! DI IKUTI PEKIK YANG LAIN

Petugas tiga : kayak mau perang aja!

Petugas dua : Diam! Bacot mu! 
Lingua Rima: Jurnal Pendidikan Program Studi Bahasa dan Sastra Indonesia

Vol.6 No.2 Juli 2017

Petugas satu : Hey, bung! Di sini yang berhak memanggil saksi, korban atau pelaku adalah saya! Jadi anda-anda ini tidak berhak se-enaknya saja memanggil siapapun tanpa persetujuan saya! Ngerti?!

YANG MAU BERANGKAT BERHENTI, TIDAK JADI MEMANGGIL PAK HAJI KOMAR

Seseorang : Trus maunya apa sih? Ditolong mau manggilin gak boleh. Ada apa ini sebenarnya? kayak ada yang ditutup-tutupi.

Seseorang : Sudah jangan didengar. Cabut aja!

Petugas satu : kalau masih ada yang masih ngeyel, terpaksa MENGAMBIL SENAPAN LAGI (h.75).

Tuturan di atas tidak sopan mengandung perselisihan pendapat dan ancaman yang dapat menyinggung perasaan mitra tuturnya, pada saat warga hendak memanggil Pak Haji Komar tetapi para petugas bersikeras untuk tidak memanggil pak Haji Komar karena dapat memperlambat penyelidikan dan petugas merasa yang berhak memanggil Pak haji adalah petugas, contohnya dalam dialog, "Hey, bung! Di sini yang berhak memanggil saksi, korban atau pelaku adalah saya! Jadi anda-anda ini tidak berhak se-enaknya saja memanggil siapapun tanpa persetujuan saya! Ngerti?!”. Tentunya tuturan tersebut mengandung bentakan yaitu kata "Hey Bung", kalimat ini tentunya menggunakan kalimat yang tinggi, tetapi para warga yang hendak memanggil Haji Komar tetap nekat, akhirnya para petugas bertutur dengan tidak santun dengan mengancam senjatanya, "kalau masih ada yang masih ngeyel, terpaksa MENGAMBIL SENAPAN LAGI”.

Tuturan antara seseorang dan para petugas tesebut melanggar maksim mufakat, karena telah meminimalkan kesepakatan di antara mereka, dan memaksimalkan ketidak sepakatan di antara mereka. maksim mufakat menggariskan setiap penutur dan lawan tutur untuk memaksimalkan kemufakatan di antara mereka, dan meminimalkan ketidak sepakatan di antara mereka. tuturan seseorang dan petugas di atas dikategorikan tuturan yang melanggar prinsip kesantunan.

\section{Pelanggaran Maksim Simpatisan}

Simpati merupakan prinsip kesantunan yang setiap pelaku tutur diwajibkan untuk ikut memahami perasaan lawan tuturnya, terutama disaat lawan tuturnya sedang gelisah atau sedih karena mendapatkan musibah atau cobaan. Dengan pemahaman rasa seperti ini diharapkan lawan tutur menjadi sedikit terhibur atau merasa nyaman saat melakukan komunikasi sosial bersama penutur. 
Petugas satu : saya terharu, saya terharu, terharu sekali. Saya terharu karena kamu miskin. Saya terharu karena kamu mempunyai kepedulian terhadap tetangga-tetangga kamu. Tetapi saya tidak terharu terhadap tipu-daya yang kamu lakukan dihadapan saya. Kamu mencoba menipu saya dengan berbagai cara yang sangat meyakinkan. Hebat, hebat, ini seperti permainan politik kelas atas, memancing, memberi umpan kemudian menariknya ketik umpan itu sudah termakan. Tapi sayangnya saya bukan ikan mujaer, ikan bandeng, atau ikan nila, saya adalah petugas yang sudah berpengalaman. Dan kalaupun diibaratkan ikan, saya ikan paus gak mungkin bisa ke pancing sama kail kelas empang seperti itu!

Wardana : Bapak hobi mancing yah?

Petugas satu : Tidak sama sekali! (h.62).

Tuturan petugas satu tidak enak didengar mengandung cacian atau olok-olokan, ketika wardana sedang bercerita tentang kehidupannya petugas satu malah mengejeknya dengan katakata," saya terharu, saya terharu, terharu sekali. Saya terharu karena kamu miskin. Saya terharu karena kamu mempunyai kepedulian terhadap tetangga-tetangga kamu. Tetapi saya tidak terharu terhadap tipu-daya yang kamu lakukan dihadapan saya" seharusnya petugas satu bersimpati atas nasib, Wardana. Tetapi petugas satu malah mengejeknya dengan mengatakan "Saya terharu karena kamu miskin" karena kata karena kamu miskin merupakan kata tidak sopan.

Tuturan yang dituturkan oleh petugas satu tersebut melanggar maksim simpatisan, maksim ini diungkapkan dengan tuturan asertif dan ekspresif, maksim simpatiasan ini mengharuskan setiap peserta tutur untuk memaksimalkan rasa simpati, dan meminimalkan rasa antipati kepada lawan tuturnya. tuturan petugas satu tersebut justru sebaliknya. yakni meminimalkan rasa simpati dan memaksimalkan rasa antipati kepada lawan tuturnya. tuturan petugas satu itu dikategorikan tuturan yang melanggar perinsip kesantunan.

\section{E. Simpulan}

Pelanggaran yang terdapat pada analisis pelanggaran prinsip kesantunan pada naskah drama Tik karya Budi Yasin Misbach, dalam Antologi Bengkel Penulisan Naskah Drama Dewan Kesenian Jakarta. Naskah yaitu 1) pelanggaran maksim penghargaan; 2) pelanggaran maksim kerendahan hati; 3) pelanggaran maksim mufakat; dan 4) pelanggaran maksim simpatisan.

\section{F. Daftar Pustaka}

Kosasih, E. (2012). Dasar-dasar Keterampilan Bersastra. Bandung: Yrama Widya.

Leech, Geoffrey. (2015).Prinsip-prinsip Pragmatik.Jakarta:Universitas Indonesia (UI Prees). 
Lingua Rima: Jurnal Pendidikan Program Studi Bahasa dan Sastra Indonesia

Vol.6 No.2 Juli 2017

Rahardi, Kun Jana. (2009). Sosiopragmatik. Jakarta: Erlangga.

Rendra, WS. (2013). Seni Drama Untuk Remaja.Bandung: PT Dunia Pustaka Jaya.

Sulistyo, Edy Tri. (2013). Pragmatik Suatu Kajian Awal: Surakarta Sebelas Maret University Press. 